\title{
Synthesis and Magnetic Properties of Conventional and Microwave Calcined Strontium Hexaferrite Powder
}

\author{
Kanagesan Samikannu ${ }^{1}$, Jesurani Sinnappan ${ }^{1,2}$, Sivakumar Mannarswamy ${ }^{1}$, Thirupathi Cinnasamy ${ }^{1}$, \\ Kalaivani Thirunavukarasu ${ }^{1}$
}

${ }^{1}$ Center for Material Science and Nano Devices Department of Physics, SRM University, Kattankulathur, India; ${ }^{2}$ Department of Physics, Jeyaraj Annapackium College for Women, Periyakulam, India.

Email: kanagu1980@gmail.com

Received December 24 ${ }^{\text {th }}, 2010$; revised March 21 ${ }^{\text {st }}, 2011$; accepted May $17^{\text {th }}, 2011$.

\begin{abstract}
Powders of strontium hexaferrite $\left(\mathrm{SrFe}_{12} \mathrm{O}_{19}-\mathrm{SrF}\right)$ have been prepared by the sol-gel process. The prepared precursor was calcined in two different calcination techniques, using conventional furnace and microwave furnace. Thermal analysis studies showed exothermic and endothermic reaction peak at room temperature to $1200^{\circ} \mathrm{C}$. An investigation of $\mathrm{SrFe}_{12} \mathrm{O}_{19}$ crystalline powder from the structural and magnetic aspect is performed using X-ray diffraction (XRD), high resolution scanning electron microscopy (HR-SEM) and vibrating sample magnetometer (VSM). The average particle diagonal size of $\mathrm{SrFe}_{12} \mathrm{O}_{19}$ powder was $80-100 \mathrm{~nm}$ in conventional and $40-70 \mathrm{~nm}$ in microwave calcinations respectively. XRD result showed the formation of $\mathrm{SrFe}_{12} \mathrm{O}_{19}$ of the sample calcined at $900^{\circ} \mathrm{C}$ with $\mathrm{Fe} / \mathrm{Sr}$ : D-Fructose ratio $=12$.
\end{abstract}

Keywords: Sol-Gel, Strontium Hexaferrite, D-Fructose, Magnetization

\section{Introduction}

The M-type Strontium Hexaferrite- $\mathrm{SrFe}_{12} \mathrm{O}_{19}(\mathrm{SrF})$ is a hard magnetic material due to its high coercivity. $\mathrm{SrFe}_{12} \mathrm{O}_{19}$ crystallize with 64 ions per unit cell on 11 different symmetry sites, the magnetic structure given by Gorter model, $24 \mathrm{Fe}^{3+}$ atoms are arranged over five distinct sites: three octahedral sites and two tetrahedral sites. These five sites are coupled via ferromagnetic superexchange interaction through $\mathrm{O}^{2-}$ ions [1]. Recently, Wang et al., reported a correlation between magnetic properties and particles morphology of $\mathrm{SrFe}_{12} \mathrm{O}_{19}$ [2]. By controlling the microstructure, morphology and chemical composition and particle size, the magnetic properties of the material can be improved. Ferrites, typically spinel ferrite and magnetoplumbite ferrite, can be used as recording materials, microwave devices, humidity sensors, pigments etc. Compared with spinel ferrite, magnetoplumbite ferrites, strontium ferrite have attracted more scientific research in recent years due to their high uniaxial magnetic anisotropy, high saturation magnetization and high coercivity $[3,4]$. In order to get homogeneous ferrite, several techniques have been used in the preparation of Sr hexaferrite, such as the chemical co precipitation [5], hydrothermal [6], sol-gel [7,8], micro emulsion [9], and citrate precursor [10] have been developed. Therefore, the preparation of $\mathrm{SrFe}_{12} \mathrm{O}_{19}$ having high purity, ultrafine size, good dispersion and excellent magnetism has been the focus of recent research $[7,11]$. The growing interest during the past decade is essentially due to the fact that microwave heat treatment could influence the microstructure can improve the material properties. Conventional furnace heating samples by the surface heating mechanism and depending on the rate of heating, a large thermal gradient from the surface to the centre can be generated within a sample, particularly with materials heaving a poor thermal conductivity. Microwave heating would be promising because it is a self-heating process of absorbing the electromagnetic energy. As a result of the internal and volumetric heating at high heating rate may lead to reduction in manufacturing cost on account of energy savings, shorter processing times and improved product uniformity and yields, limited grain growth throughout the ceramic body. It is well known that the heating rate and thermal efficiency of the microwave heating is higher than those of conventional method [12, 13]. In this paper, we report the preparation of $\mathrm{SrFe}_{12} \mathrm{O}_{19}$ 
by sol-gel process and important hysteresis parameters of the powders with influence of convention and microwave calcinations.

\section{Experimental}

The powder was prepared by sol-gel technique using D-Fructose as the fuel. Analytical grade $\mathrm{Ba}\left(\mathrm{NO}_{3}\right)_{2}$, $\mathrm{Fe}\left(\mathrm{NO}_{3}\right)_{3} \cdot 9 \mathrm{H}_{2} \mathrm{O}$ and D-Fructose were used as starting materials. Nitrate and fuel ratio is 1:1. Stoichiometric amount of metal nitrates and fuel were taken, dissolved in distilled water and stirred by magnetic stirrer for $2 \mathrm{~h}$ to get a solution. Sol was heated at $80^{\circ} \mathrm{C}$ with stirring continuously, finally it changed in to sticky liquid gel and it was preheated at $130^{\circ} \mathrm{C}$ in a hot air oven for two days to get precursor. The precursor was calcined (Conventional and microwave) at $900^{\circ} \mathrm{C}$, to get crystalline barium hexaferrite powder.

\subsection{Characterization}

Thermo gravimetric analysis of the mixture composed of barium nitrate, iron nitrate and D-Fructose (precursor) were carried out between $28^{\circ} \mathrm{C}$ and $1200^{\circ} \mathrm{C}$ on NETZSCH STA $409 \mathrm{C} / \mathrm{CD}$ in the static air atmosphere at the heating rate of $10^{\circ} \mathrm{C}$ per minute. The DTA analyses of same mixtures were also carried out on the same instrument at same condition. The crystalline phases were identified by means of X-ray diffraction (XRD) measurements (PANalytical X'pert pro) $\mathrm{CuK} \alpha$ radiation at $45 \mathrm{kV}$ and $40 \mathrm{~mA}$ $(\lambda=0.15406 \mathrm{~nm})$ in a wide range of $2 \theta\left(10^{\circ}<2 \theta<80^{\circ}\right)$. The surface morphology and size of the ferrite particles were studied by using FEI Quanta FEG 200-High resolution scanning electron microscope (HR-SEM) and Magnetization measurements at room temperature were carried out on Lakeshore Vibrating Sample Magnetometer (VSM) at a maximum applied field of 15,000 Gauss at room temperature.

\section{Results and Discussion}

The thermogram of the precursor of barium hexaferrite derived by mixing of barium nitrate, ferric nitrate and D-Fructose as shown in Figure 1. TGA shows the initial weight loss from $28^{\circ} \mathrm{C}$ to $185^{\circ} \mathrm{C}$ due to the loss of absorbed water [14]. The subsequent loss up to $400^{\circ} \mathrm{C}$ is associated mainly to the decomposition of the D-fructose. In order to verify this, separate TGA was undertaken for D-fructose, thermogram is shown in Figure 2. It shows the major weight loss between $200^{\circ} \mathrm{C}$ and $400^{\circ} \mathrm{C}$ thus supporting our assignment. Therefore, D-Fructose provides self heat to promote the reaction and to reduce the crystallization temperature of the hexaferrite. The stage of decomposition between $400^{\circ} \mathrm{C}$ and $775^{\circ} \mathrm{C}$ is due to decomposition of nitrates and starting formation of hexaferrite. There is no considerable weight loss above

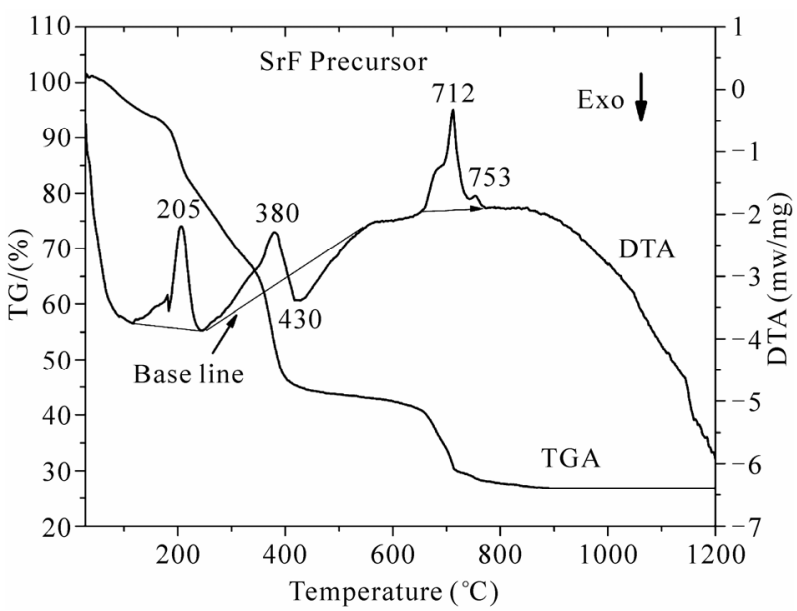

Figure 1. TG-DTA curves for the precursor.

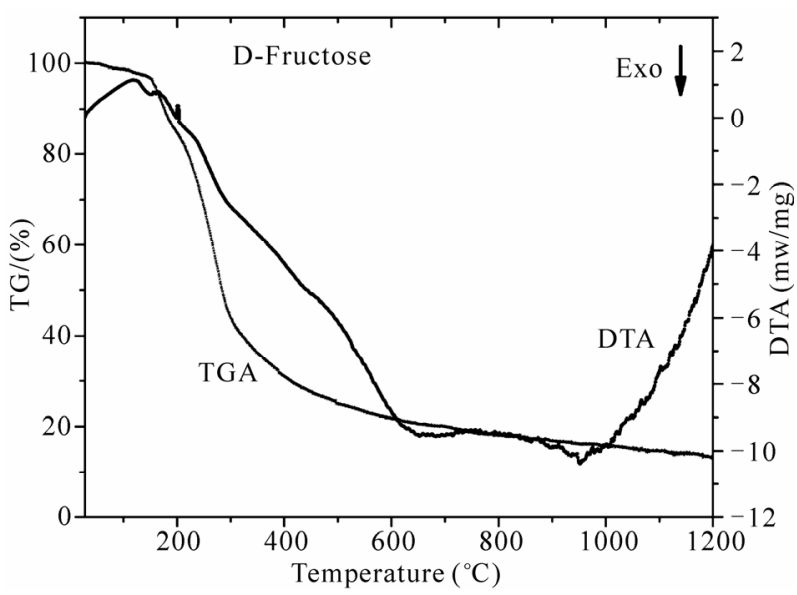

Figure 2. TG-DTA curves for D-fructose.

$900^{\circ} \mathrm{C}$, confirming the formation of the stable Strontium hexaferrite this analysis, therefore illustrates the optimum calcinations temperature for Strontium hexaferrite is around $900^{\circ} \mathrm{C}$.

The sequences of reaction taking place is shown in the following steps

$$
\begin{gathered}
\text { Precursor } \stackrel{200^{\circ} \mathrm{C}-500^{\circ} \mathrm{C}}{\longrightarrow} \mathrm{Fe}_{2} \mathrm{O}_{3}+\mathrm{SrO} \\
\mathrm{Fe}_{2} \mathrm{O}_{3}+\mathrm{SrO} \stackrel{250^{\circ} \mathrm{C}-750^{\circ} \mathrm{C}}{\longrightarrow} \mathrm{SrFe}_{2} \mathrm{O}_{4} \\
5 \mathrm{Fe}_{2} \mathrm{O}_{3}+\mathrm{SrFe}_{2} \mathrm{O}_{4} \stackrel{\text { above } 750^{\circ} \mathrm{C}}{\longrightarrow} \mathrm{SrFe}_{12} \mathrm{O}_{19}
\end{gathered}
$$

Figure 3 shows the XRD patterns of the powders conventionally calcined at temperatures $500^{\circ} \mathrm{C}, 750^{\circ} \mathrm{C}$ and $900^{\circ} \mathrm{C}$ for $3 \mathrm{~h}$ in air, respectively. The precursor is calcined at $500^{\circ} \mathrm{C}$; the powders can be described as $\mathrm{Fe}_{2} \mathrm{O}_{3}$ and $\mathrm{SrO}$ and then the phase of $\mathrm{SrFe}_{2} \mathrm{O}_{4}$ and hexagonal $\mathrm{SrFe}_{12} \mathrm{O}_{19}$ can been detected for samples calcined at $750^{\circ} \mathrm{C}$. Clear diffraction peak of $\mathrm{SrFe}_{12} \mathrm{O}_{19}$ can be obtained at $900^{\circ} \mathrm{C}$, which coincides with the JCPDS file 
number: 84-1531. Calcination temperature and intermediate $\mathrm{Fe}_{2} \mathrm{O}_{3}$ plays an important role in the formation of Strontium Hexaferrite. The phase development microwave calcined powder at different temperatures, $500^{\circ} \mathrm{C}$, $750^{\circ} \mathrm{C}$ and $900^{\circ} \mathrm{C}$ for 10 minutes, the peaks corresponding to the standard diffraction pattern of $\mathrm{SrO}, \mathrm{SrFe}_{2} \mathrm{O}_{4}$ and $\mathrm{SrFe}_{12} \mathrm{O}_{19}$ and is shown in Figure 4.

In order to visualize the conventional calcined powder are in elongated hexagonal like structure, diagonal size vary in the range of $80-100 \mathrm{~nm}$ and it is not well defined shape (Figure 5). The HR-SEM micrograph for the microwave calcined powder at $900^{\circ} \mathrm{C}$ for 10 minutes is shown in Figure 6. The particles are hexagonal platelets and well crystalline strontium ferrite, diameters are in the range of $40 \mathrm{~nm}$ to $70 \mathrm{~nm}$. This type of shape is usually observed for $\mathrm{BaFe}_{12} \mathrm{O}_{19}$ or $\mathrm{SrFe}_{12} \mathrm{O}_{19}$ obtained by sol-gel process $[4,15]$. The morphology of the microwave calcined powder samples reveal smaller particles compared

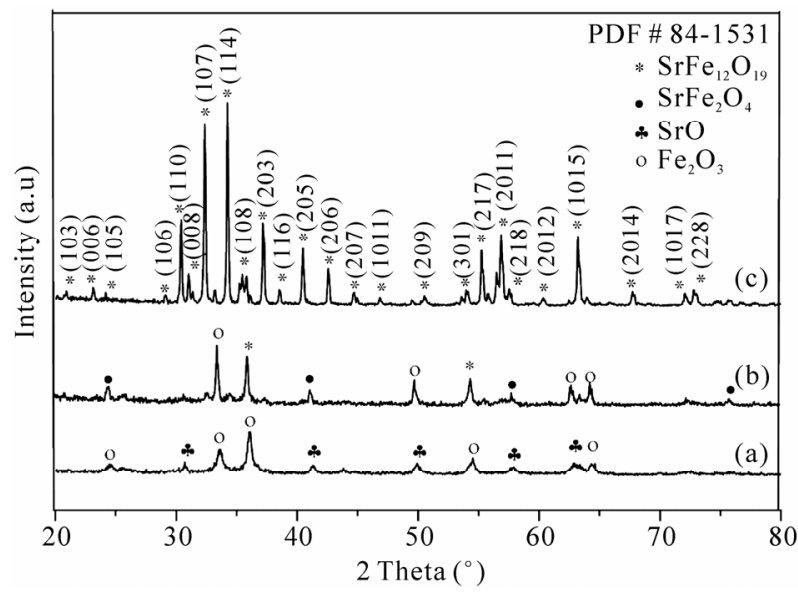

Figure 3. XRD patterns of the powders calcined at different temperatures: (a) $500^{\circ} \mathrm{C}$, (b) $750^{\circ} \mathrm{C}$, and (c) $900^{\circ} \mathrm{C}$ for $3 \mathrm{~h}$.

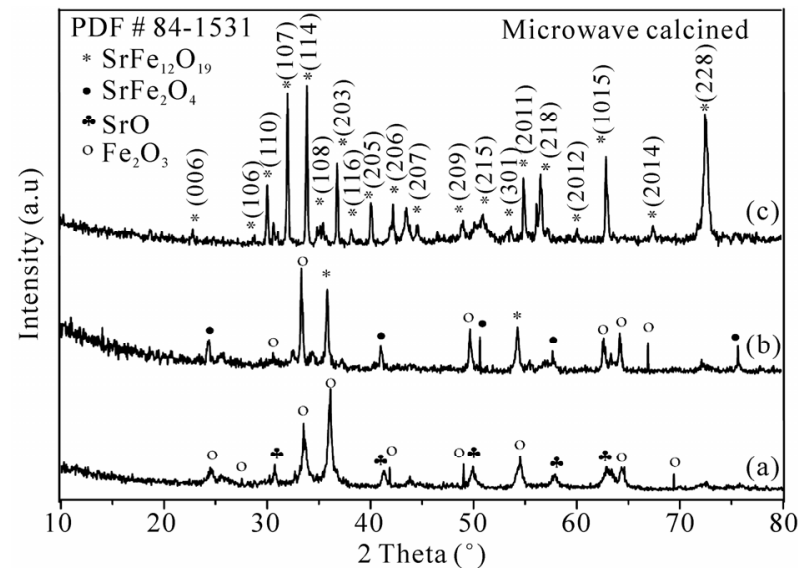

Figure 4. XRD patterns of the powders microwave calcined at different temperatures: (a) $500^{\circ} \mathrm{C}$, (b) $750^{\circ} \mathrm{C}$, and (c) $900^{\circ} \mathrm{C}$ for 10 minutes.

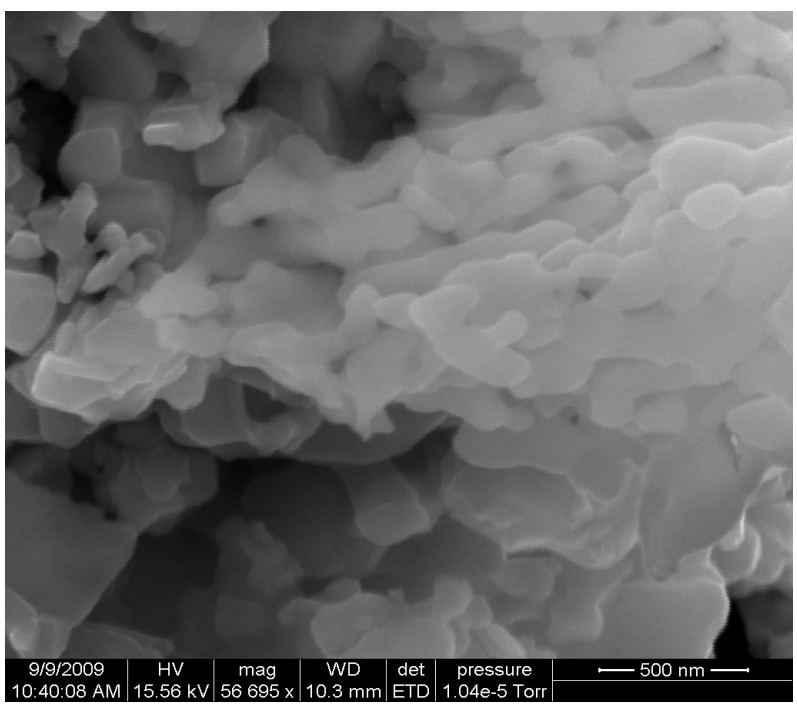

Figure 5. HR-SEM image of conventionally calcined powder at $900^{\circ} \mathrm{C}$ for $3 \mathrm{~h}$.

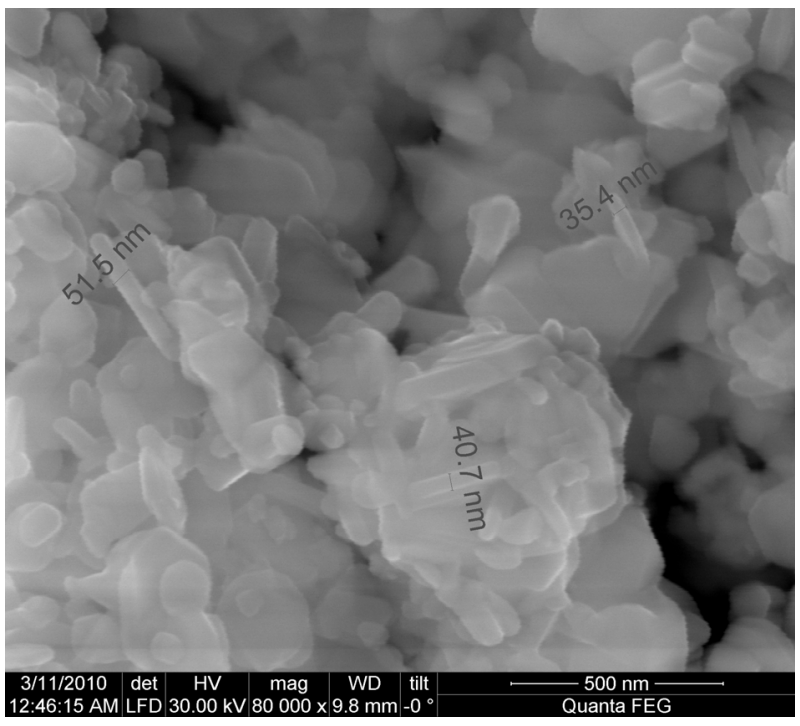

Figure 6. HR-SEM image of microwave calcined powder at $900^{\circ} \mathrm{C}$ for 10 minutes.

to the conventionally calcined powder. Hard magnetic materials with hexagonal structure is mainly due to the microwave energy coupled through polarization, electronic and ionic conductivity loss therefore a smaller particle size resulted from the enhanced diffusion and accelerated densification [16].

Figure 7 shows the magnetization versus applied field for conventional and microwave treated samples at room temperature. The reduction in $\mathrm{M}_{\mathrm{s}}$ in microwave calcined powder can be attributed to the decrease in the size of the particles. The observed value of saturation magnetization $47 \mathrm{~A} \cdot \mathrm{m}^{2} / \mathrm{kg}$ for the sample conventionally calcinated at $900^{\circ} \mathrm{C}$ are far from the theoretical $\mathrm{M}_{\mathrm{s}}$ value of 74.3 


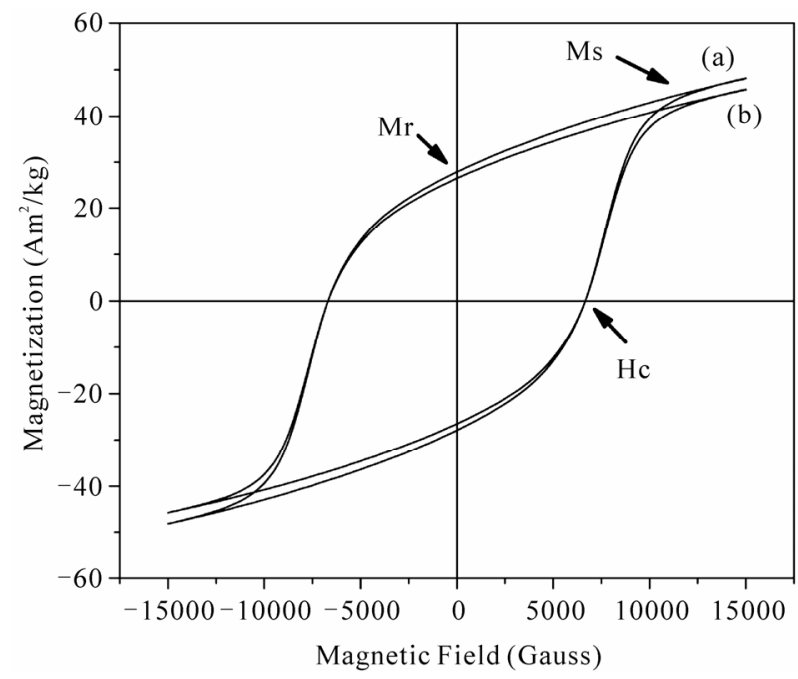

Figure 7. Magnetization curve of $\mathrm{SrFe}_{12} \mathrm{O}_{19}$ (a) powder conventionally calcined at $900^{\circ} \mathrm{C}$ for $3 \mathrm{~h}$; (b) powder microwave calcined at $900^{\circ} \mathrm{C}$ for 10 minutes.

A. $\mathrm{m}^{2} / \mathrm{kg}$ and the coercivity 6,709 Gauss very close to the theoretical $\mathrm{H}_{\mathrm{c}}$. Observed magnetization values are close to those observed in other methods of preparation (50 $\left.60 \mathrm{Am}^{2} / \mathrm{kg}\right)[5,6,10,17]$. The value of $\mathrm{M}_{\mathrm{r}}\left(26.58 \mathrm{Am}^{2} / \mathrm{kg}\right)$ is approximately $59 \%$ of $\mathrm{M}_{\mathrm{s}}$ it has maximum coercivity of 6,708 Gauss for microwave calcined powder is lower than those of the literature and of the theoretical limit (7,500 Gauss) [18]. The samples calcined conventionally and microwave at $900^{\circ} \mathrm{C}$ shows smooth hysteresis loop, which confirms the formation of pure strontium hexaferrite $[18,19]$.

\section{Conclusions}

The effective influence of conventional and microwave on the structure and magnetic properties crystalline $\mathrm{SrFe}_{12} \mathrm{O}_{19}$ are discussed. The samples were subjected to two different heat treatments. From the analysis of various characterization techniques such as XRD, HR-SEM and VSM, we observe that the structure remained intact with different heating treatment process. The possibility of lowering the synthesis temperature and get a pure SrF powder, microwaves allows the reduction of particle size in the hexaferrite. The external diameters of the obtained different method of calcined $\mathrm{SrFe}_{12} \mathrm{O}_{19}$ particles range between 40 to $100 \mathrm{~nm}$. The results indicate that calcinations method has significant effect on the saturation magnetization $\left(\mathrm{M}_{\mathrm{s}}\right)$. These magnetic materials can potentially be used in micro/nano electronic devices, gas sensors and catalysts.

\section{Acknowledgements}

The authors thank SRM University for providing the facilities available in Nanotechnology center.

\section{REFERENCES}

[1] J. F. Wang, C. B. Ponton and I. R. Harris, "A Study of Sm-Substituted SrM Magnets Sintered Using Hydrothermally Synthesized Powders," Journal of Magnetism and Magnetic Materials, Vol. 298, No. 2, 2006, pp. 122-131. doi:10.1016/j.jmmm.2005.03.012

[2] Y. Wang, Q. Li, C. Zhang and B. Li, "Preparation and Magnetic Properties of Different Morphology Nano$\mathrm{SrFe}_{12} \mathrm{O}_{19}$ Particles Prepared by Sol-Gel Method," Journal of Alloys and Compounds, Vol. 467, No. 7, 2009, pp. 284-287.

[3] B. S. Zlatkova, M. V. Nikolicb, O. Aleksicb, H. Danningerc and E. Halwax, "A Study of Magneto-Crystalline Alignment in Sintered Barium Hexaferrite Fabricated by Powder Injection Molding," Journal of Magnetism and Magnetic Materials, Vol. 321, No. 4, 2009, pp. 330-335. doi:10.1016/j.jmmm.2008.09.014

[4] H. Shang, J. Wang and Q. F. Liu, "Synthesis and Characterization of Nanocrystalline $\mathrm{BaFe}_{12} \mathrm{O}_{19}$ Obtained by Using Glucose as a Fuel," Materials Science and Engineering: A, Vol. 456, No. 15, May 2007, pp. 130-132. doi:10.1016/j.msea.2006.12.011

[5] X. Liu, J. Wang, L. M. Ganb and S. C. Ng, "Improving the Magnetic Properties of Hydrothermally Synthesized Barium Ferrite," Journal of Magnetism and Magnetic Materials, Vol. 195, No. 2, 1999, pp. 452-459. doi:10.1016/S0304-8853(99)00123-7

[6] A. Ghasemi, A. Morisako and X. Liu, "Magnetic Properties of Hexagonal Strontium Ferrite Thick Film Synthesized by Sol-Gel Processing Using SrM Nanoparticles," Journal of Magnetism and Magnetic Materials, Vol. 320, No. 18, 2008, pp. 2300-2304. doi:10.1016/j.jmmm.2008.04.156

[7] P. C. A. Britoa, R. F. Gomesa, J. G. S. Duqueb and M. A. Macedo, "SrFe ${ }_{12} \mathrm{O}_{19}$ Prepared by the Proteic Sol-Gel Process," Physica B: Condensed Matter, Vol. 384, No. 1, 2006, pp. 91-93. doi:10.1016/j.physb.2006.05.159

[8] R. M. Garcia, E. R. Ruiz and E. E. Rams, "Structural Characterization of Low Temperature Synthesized $\mathrm{SrFe}_{12} \mathrm{O}_{19}$," Materials Letters, Vol. 50, No. 2-3, 2001, pp. 183-187. doi:10.1016/S0167-577X(01)00222-1

[9] S. Chaudhury, S. K. Rakshit, S. C. Parida, Z. Singh, K. D. Singh Mudhera and V. Venugopal, "Studies on Structural and Thermo-Chemical Behavior of $\mathrm{MFe}_{12} \mathrm{O}_{19}(\mathrm{~s})(\mathrm{M}=\mathrm{Sr}$, $\mathrm{Ba}$ and $\mathrm{Pb}$ ) Prepared by Citrate-Nitrate Gel Combustion Method," Journal of Alloys and Compounds, Vol. 455, No. 1-2, 2008, pp. 25-30. doi:10.1016/j.jallcom.2007.01.075

[10] W. Zhong, W. Ding, N. Zhang, J. Hong, Q. Yan and Y. $\mathrm{Du}$, "Key Step in Synthesis of Ultrafine $\mathrm{BaFe}_{12} \mathrm{O}_{19}$ by Sol-Gel Technique," Journal of Magnetism and Magnetic Materials, Vol. 168, No. 1-2, 1997, pp. 196-202. doi:10.1016/S0304-8853(96)00664-6

[11] Z. Y. Wang, L. M. Zhong, J. L. Lv, H. C. Qian, Y. L. Zheng, Y. Z. Fang, M. L. Jin and J. Y. Xu, "MicrowaveAssisted Synthesis of $\mathrm{SrFe}_{12} \mathrm{O}_{19}$ Hexaferrites," Journal of 
Magnetism and Magnetic Materials, Vol. 322, No. 18, 2010, pp. 2782-2785. doi:10.1016/j.jmmm.2010.04.027

[12] Y. Fang, R. Roy, D. K. Agrawal and D. M. Roy, "Transparent Mullite Ceramics from Diphasic Aerogels by Microwave and Conventional Processing," Materials Letters, Vol. 28, No. 1-3, 1996, pp. 11-15. doi:10.1016/0167-577X(96)00028-6

[13] A. Kishimoto, M. Ito and S. Fujitsu, "Microwave Sintering of ion Conductive Zirconia Based Composite Dispersed with Alumina," Journal of Materials Science Letters, Vol. 20, No. 10, 2001, pp. 943-945. doi:10.1023/A:1010945320700

[14] A. Ataie, S. Heshmatimanesh and H. Kazempour, "Synthesis of Barium Hexaferrite by the Co-Precipitation Method Using Acetate Precursor," Journal of Materials Science, Vol. 37, No. 10, 2002, pp. 2125-2128. doi:10.1023/A:1015254221872

[15] R. M. Garcia, E. R. Ruiz and E. E. Rams, "Structural Characterization of Low Temperature Synthesized $\mathrm{SrFe}_{12} \mathrm{O}_{19}$," Materials Letters, Vol. 50, No. 2-3, 2001, pp. 183-187. doi:10.1016/S0167-577X(01)00222-1
[16] Z. Xie, Z. Gui, L. Li, X. Huang and Y. Huang, "Characterization of Lead Based Relax or Ferroelectric Ceramics Sintered in a $2.45 \mathrm{GHz}$ Microwave Radiation," Journal of Materials Science, Vol. 35, No. 1, 2000, pp. 203-207.

[17] D. H. Chen and Y. Y. Chen, "Synthesis of Strontium Ferrite Nanoparticles by Coprecipitation in the Presence of Polyacrylic Acid," Materials Research Bulletin, Vol. 37, No. 4, 2002, pp. 801-810. doi:10.1016/S0025-5408(01)00590-6

[18] N. Kumar, A. Kumar, R. Jha, A. Dogra, R. Pasricha, R. K. Kotnala, H. Kishan and V. P. S. Awana, "Impact of Particle Size on Room Temperature Ferrimagnetism of $\mathrm{SrFe}_{12} \mathrm{O}_{19}$," Journal of Superconductivity and Novel Magnetism, Vol. 23, No. 4, 2010, pp. 423-427. doi:10.1007/s10948-010-0766-0

[19] Y. Wang, Q. Li, C. Zhang and B. Li, "Effect of Fe/Sr Mole Ratios on the Formation and Magnetic Properties of $\mathrm{SrFe}_{12} \mathrm{O}_{19}$ Microtubules Prepared by Sol-Gel Method," Journal of Magnetism and Magnetic Materials, Vol. 321, No. 19, 2009, pp. 3368-3372. doi:10.1016/j.jmmm.2009.05.066 